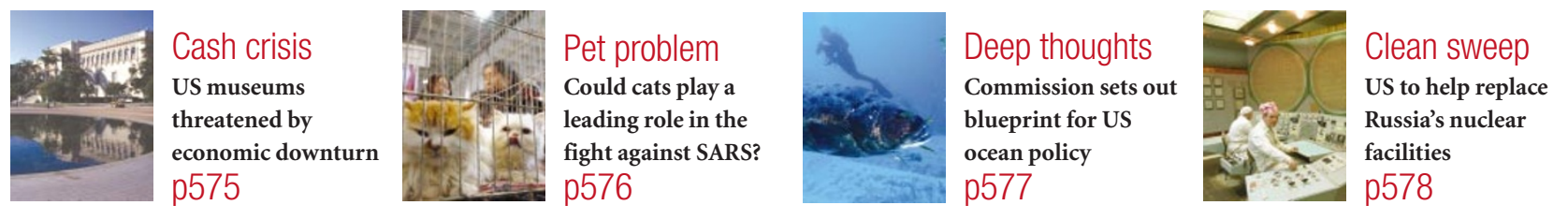

\title{
Harmful potential of viral vectors fuels doubts over gene therapy
}

\section{Erika Check, Washington}

The troubled field of gene therapy was dealt a fresh blow this week, after a study suggested that modified viruses used in some trials might cause health problems.

The study, led by geneticist Mark Kay at Stanford University, California, examined a modified virus used in gene-therapy trials to treat haemophilia and cystic fibrosis. It revealed that the virus has the potential to cause the same problems that led to cancer in an unrelated gene-therapy trial last year.

In gene therapy, doctors use a gutted virus as a 'vector' to transfer corrective genes into a patient's cells. But if the vector stitches itself into a cell's genes, it can cause the cell to mutate and become cancerous. This was demonstrated last year, when two children who had gene therapy for severe combined immunodeficiency disease (SCID) developed leukaemia (see Nature 419, 545-546; 2002).

Scientists are still trying to establish exactly why the SCID patients developed cancer, and will discuss the trial at this week's meeting of the American Society of Gene Therapy in Washington DC. But most agree that gene therapy was the cause.

Kay's study focused on a vector made from an adeno-associated virus - an organism that does not cause disease in people, but

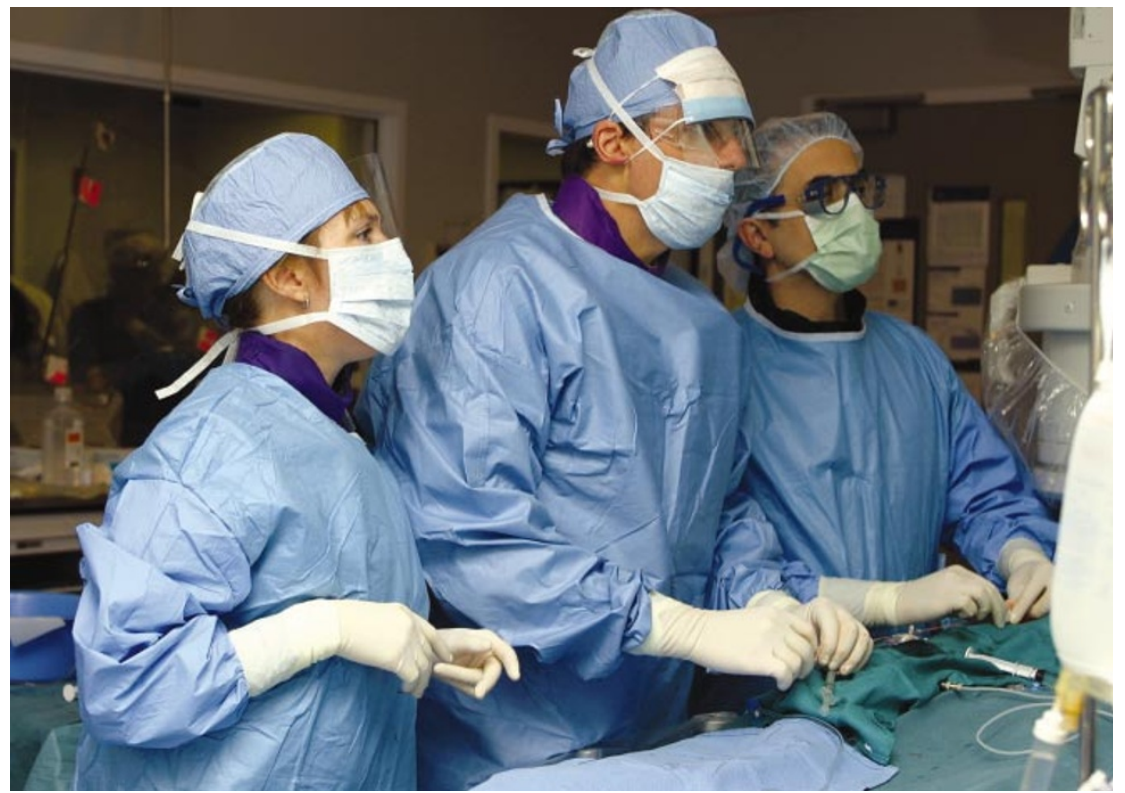

Doctors at Stanford treat a haemophiliac in a gene-therapy trial - but how safe is the procedure?

which can be engineered to infect human cells. In a paper published online on 1 June (H. Nakai et al. Nature Genet. doi:10.1038/ ng1179; 2003), Kay and his colleagues show that the vector used in the haemophilia and cystic fibrosis trials integrates itself more often into genes than it does into regions of DNA that do not contain genes. The finding suggests that the vector could potentially cause the sort of cellular defects that led

\section{Protests win reprieve for renowned medical lab}

\section{Jim Giles, London}

The UK Medical Research Council (MRC)

has shelved plans to close its largest laboratory, at Mill Hill in north London at least for the time being.

In April, the MRC proposed that the prestigious National Institute for Medical Research should move to Addenbrooke's Hospital in Cambridge, 50 miles away (see Nature 422,$545 ; 2003)$. MRC officials said that the move would save money and improve interactions between basic and clinical researchers.

But the plan infuriated biomedical researchers at Mill Hill, who said they already had a strong track record of collaborating with clinical researchers at various London hospitals, which employ a wider range of specialists than is found at Addenbrooke's.

Now their protests, which were supported by several Members of Parliament, seem to have hit home. In a letter sent on 30 May to John Skehel, a virologist and director of the Mill Hill institute, MRC chief executive George Radda said that the council would abandon its original intention of reaching a decision on the move by next month.

Radda said that the future of the institute would instead be decided by a task force chaired jointly by himself and Colin Blakemore, the University of Oxford neuroscientist who will succeed him as chief executive in October (see Nature 423, 211; 2003).

Unlike the subcommittee behind the original proposal, the task force will include scientists from Mill Hill itself, as well as from outside Britain. "This is a step forward in terms of consultation," says Skehel.

Despite their relief at the reprieve, researchers at Mill Hill say that they are still worried that continuing uncertainty could damage the institute. 
to cancer in the SCID patients.

But researchers caution that the vector used in the SCID trials, which was based on a retrovirus, is very different from the adeno-associated vector. For instance, retroviruses must insert themselves into human DNA to work, but adeno-associated viral vectors integrate themselves into the genome much less often.

"Adeno-associated vectors clearly have a better safety profile than retroviral vectors," says David Russell, a geneticist at the University of Washington in Seattle. "But we really can't say yet that adenoassociated vectors won't cause cancer."

Kay's team, which is running a genetherapy trial for haemophilia, tracked the adeno-associated viral vectors in mice. They extracted liver cells whose DNA contained the vector and then sequenced the DNA around the vector. They then analysed the sequences to see whether they matched a known gene. The team found that $72 \%$ of the time, the vector had interrupted a gene. Had it inserted itself randomly, the vector would have interrupted a gene no more than $40 \%$ of the time.

Last August, Frederic Bushman and his colleagues at the Salk Institute for Biological Sciences in La Jolla, California, suggested that retroviruses also insert themselves into genes more often than into other regions of DNA (A. R. Schroder et al. Cell 110, 521-529; 2002).

Such results are leading researchers to seek better ways to target vectors to specific regions of DNA, and to develop vectors that don't integrate into DNA at all. But in the meantime, Kay says that he has taken numerous precautions to protect the 14 haemophiliacs he has treated.

"I don't think we need to modify anything at this point," Kay says. "But this is a risk we'll have to address before the vector is in widespread use."

\section{Divisions sink US consensus effort on transgenic food}

Jonathan Knight, San Francisco

An ambitious effort to hammer out an agreement between proponents and critics of agricultural biotechnology in the United States has ended in failure.

Two years of talks, convened in 2001 by the Washington-based Pew Initiative on Food and Biotechnology, reached an impasse late last month over the question of whether to ask Congress for legislation to strengthen regulations for transgenic food.

The 18-member panel was set up to produce detailed guidelines for safety standards for genetically modified products. But the ground rules for the panel required unanimous agreement on all issues under consideration before any conclusions would be made public. "It was an extremely ambitious effort," says Margaret Mellon, a panel member and director of the food and environment programme at the Union of Concerned Scientists in Washington DC. "We were going for the brass ring, and we didn't get it."

One issue that was contentious from the start was whether new laws are needed to guarantee the safety of transgenic food. The biotechnology industry opposes the involvement of Congress in favour of minor administrative changes to the current approval process. But consumer and environmental groups say that the present voluntary system is inadequate and needs a legislative fix. Panel members confirm that disagreement on this point was critical to the failure of the process.

Some observers suggest that the recent trade complaint filed at the World Trade Organization (WTO) by the United States against the European Union (see Nature 423, 369; 2003) might have contributed to the

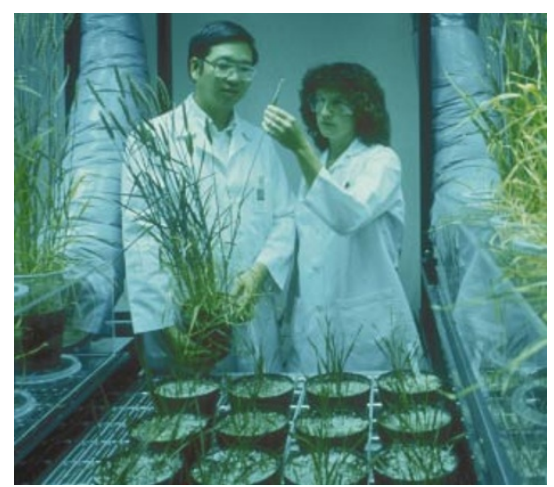

Hard to swallow: regulations on transgenic food proved a sticking point in US round-table talks.

problem by entrenching industry's position. "The case is being made on the grounds that the current regulatory process is safe," says Robert Paarlberg, an expert in international agricultural policy at Wellesley College near Boston. “The industry doesn't want any suggestion that it isn't."

Panel member Richard Caplan, an environmental advocate with the US Public Interest Research Group in Washington DC, says that although the WTO suit was not discussed in the sessions, it could have been a factor. But Mike Rodemeyer, executive director of the Pew Initiative, says that he strongly doubts whether it made any difference.

The panel's final report, issued on 30 May, left open the possibility of reconvening in 12-18 months' time. If consumers outside the United States continue to resist transgenic food, US food exporters might feel pressure to conform to tougher regulation, some panel members say.

\section{UK universities face star treatment in funding revamp}

\section{Jim Giles, London}

The seven-point scale used to assess research in British university departments could be scrapped under plans unveiled on 28 May.

The Research Assessment Exercise (RAE), a five-yearly audit of research, is widely credited with strengthening British science. But scientists have complained that the rankings are sometimes arbitrary, and give no credit to good researchers working in average departments.

Under the proposal, drawn up by Gareth Roberts, president of Wolfson College at the University of Oxford, each researcher's work would be allocated between zero and three stars, and each department's 'score' would be the sum of the scores of its individual researchers, providing a measure of the overall volume of quality work produced.

Roberts says that individual ratings would not be published, but sceptics doubt whether the scores could be kept from researchers. "How will that information be denied them?" asks Keith Peters, an immunologist at the University of Cambridge and president of the Academy of Medical Sciences. Roberts concedes that individual rankings should not be used if they cannot be kept secret.

Roberts' review, which was commissioned by the UK higher-education funding councils, also suggests separating out the least researchintensive universities and subjecting them to a shorter review process. That idea has drawn fire from some of the smaller universities. "It is divisive," says Mike Saks, pro-vicechancellor for research at the University of Lincoln. The university received just $\mathfrak{\$ 2 5 0 , 0 0 0}$ this year from the funding councils, but Saks says it has begun a major drive to improve its research and doesn't want to be put in a second class of institutions.

The funding councils, which distribute $\mathfrak{E} 1.1$ billion (US $\$ 1.8$ billion) to universities each year, largely on the basis of the RAE, are accepting comments on the new plan until September. They will then decide how to do the next assessment, most likely in 2007. www.rareview.ac.uk 